\title{
“HEALTH FOR ALL”. THE MEDICAL SYSTEM IN WALLACHIA UNDER PROTOMEDICUS NICOLAE GUSSI 1848-1859
}

\author{
"ZDRAVLJE ZA SVE". MEDICINSKI SUSTAV \\ U POKRAJINI VLAŠKA POD VODSTVOM \\ PROTOMEDIKUSA NICOLAEA GUSSIJA 1848. - 1859.
}

\author{
Lidia Trăuşan-Matu*
}

\begin{abstract}
SUMMARY
The main objective of this study is to provide an overview of the evolution of the medical system in Wallachia between 1840 and 1860 and the very important role of physician Nicolae Gussi (I802-1869), protomedicus of Wallachia between 1840 and I859, to transform medicine into a modern public service, accessible to the entire population. Particularly, we will refer to the medical reform project of 1853 , which Gussi implemented during the time he headed the medical-sanitary administration. We will insist on the details of the project because it was designed to create a network of county hospitals that would improve the health of the population and, in the medium and long term, would reduce mortality and increase life expectancy. Another dimension of the study aims at the tenure of physicians in county hospitals and describes the medical services they provided to patients, particularly from the poor population.
\end{abstract}

Keywords: medical institutions, medical policies, physicians, disease, modernization

Correspondence Address: Lidia Trăușan-Matu, History of Medicine Department, University of Medicine and Pharmacy "Carol Davila", Bucharest, Romania.

ORCID ID: https://orcid.org/0000-0001-8111-9975.

E-mail: lidia.trausan@umfcd.ro; lidiatrausan@gmail.com. 


\section{INTRODUCTION}

The aim of this article is to provide a new perspective on the modernisation of the medical system in Wallachia between 1840 and 1859 when physician Nicolae Gussi (1802-1869) headed the medical sanitary administration. The fundamental question from which this research starts is: How did the power in Wallachia manage to develop a medical strategy that would ensure the medicalisation of the population, given that Wallachia was just moving towards the Western model of modernisation and everything needed to be organised. The comparison between the situation in Wallachia and that in the surrounding states, before, during, and after the period studied by herein, helped us to give a pertinent answer to this question.

In the following pages, we will particularly refer to the medical reform of I853, which physician Nicolae Gussi implemented for six years. We are interested in showing how and how much of the health legislation of the period becomes a social reality. We will insist on the details of this project because it was meant to provide some free medical services to the population, especially to poor groups. We will discuss the newly established medical institutions, the professional body and medical services, the diseases and patients, the health legislation and the state's attempts to impose a modern, Western type of medicine instead of traditional therapeutic practices.

Through this kind of problematisation, we want to provide an overview of the process of institutionalisation of the medical system in Wallachia, especially since the beginning of this process has been very little researched in Romanian historiography. Most studies so far (historical, sociological, medical, ethnographic, anthropological) favour the period after the unification of Wallachia with Moldavia (1859), when physician Carol Davila was appointed to lead the medical system and began the process of unification of health systems in the two countries, followed by its organisation and consolidation at the national level according to the French sanitary system model. At the same time, we want to keep up with international research and connect our research topic to the interdisciplinary theme of international historiographical debates, which discuss identical or similar historical processes from different angles. We hope that the study will stimulate the research in this field.

Even if the studies published so far favour the period between 1860 and I9IO, we could find in them the relevant information related to the organisation of the medical system in the years 1830-1859. A good example is recent 
works of Călin Cotoi $^{1}$, Constantin Bărbulescu ${ }^{2}$, Ligia Livadă-Cadeschi ${ }^{3}$, Octavian Buda ${ }^{4}$, Constanța Vintilă-Ghițulescu ${ }^{5}$, etc. Regarding the emergence of medical professions in Transylvania, there is the case study of Teodora Daniela Sechel ${ }^{6}$. In Western historiography, the history of the medical professions and the history of medicine in general, is very well represented. We mention here the works of Ute Frevert ${ }^{7}$, Monika Steffen ${ }^{8}$, David Gentilcore ${ }^{9}$, Thomas Broman ${ }^{10}$ and Charles McClelland. ${ }^{11}$ Many of the problems we analysed in this study are theoretically based on these works.

The subject of this study revolves around physician Nicolae Gussi, the director of the Wallachian medical system between I840 and I859 and one of the rapporteurs of the 1853 reform of county hospitals. Therefore, I will begin the research with a short presentation of this public figure. Nicolae Gussi

1 Cotoi, Călin (2016), Cholera, Health for All, Nation-Building, and Racial Degeneration in Nineteenth-Century Romania, East-central Europe, 43 (1-2), 167-168. https://www.researchgate.net/publication/308677829. (accessed: 01 June 2020).

2 Bărbulescu, Constantin (2018). Physicians, Peasants and Modern Medicine: Imagining Rurality in Romania, 1860-1910, Budapest: Central European University Press.

3 Livadă-Cadeschi, Ligia (2013). Discursul medico-social al igeniștilor români. Abordarea specificităților locale din perspective experiențelor occidentale europene, secolele XIXXX [The medical-social discourse of the Romanian hygienists. Approaching local specificities from the perspectives of Western European experiences, 19th-20th centuries], Bucharest: Editura Muzeului Național al Literaturii Române.

4 Buda, Octavian (2013). Identitate națională și medicină socială. Antropologie culturală, psihiatrie și eugenism în România, 1800-1914 [National identity and social medicine. Cultural anthropology, psychiatry and eugenics in Romania, 1800-1914], Bucharest: Editura Muzeului Național al Literaturii Române.

5 Vintilă-Ghițulescu, Constanța (2015). Patimă și desfătare Despre lucrurile mărunte ale vieții cotidiene în societatea românească (1750-1860) [Passion and delight About the small things of daily life in Romanian society (1750-1860)], Bucharest: Humanitas.

6 Sechel, Teodora, Daniela (2008), The Emergence of the Medical Profession in Transylvania (1770-1848), in Victor Karadi, Borbala Zsuzsanna Törők eds, Cultural Dimensions of Elite Formation in Transylvania (1770-1950), Cluj-Napoca: Ethnocultural Diversity in Romania Series, 95-114.

7 Frevert, Ute (1985), Professional Medicine and the Working Classes in Imperial Germany, The Journal of Contemporary History, 20, 637-638.

8 Steffen, Monika (1987), The medical profession and the state in France, Journal of Public Policy, 7, (2), 189-208.

9 Gentilcore, David (1994). "All that pertains to medicine": protomedici and protomedicati in early modern Italy, Medical History, 38, 121-142. https://www.academia.edu/4028459/All_that_pertains_to_medicine_protomedici_and_protomedicati_in_early_modern_Italy_ (accessed: 08 June 2020).

10 Broman, Thomas (1995), Rethinking Professionalization: Theory, Practice, and Professional Ideology in Eighteenth-Century German Medicine, The Journal of Modern History, 67, 4, 837.

11 McClelland, Charles (1991). The German Experience of Professionalization: Modern Learned Professions and Their Organization from the Early Nineteenth Century to the Hitler Era (New York: Cambridge University Press. 
was born in Vurbiani, Greece, on 7 July I802, into a family of merchants. ${ }^{12}$ After receiving the title of "doctor of medicine and surgery" at the Faculty of Medicine in Paris (with the thesis Les deviations de la colonne vertébrale), he came to Wallachia and settled in Bucharest. It was I828, and Nicolae Gussi was 26 years old. Until he was appointed protomedicus of Wallachia, he was a district physician in Bucharest for ten years (between I830 and I840). ${ }^{13}$ Before that period, he was the director of the Mărcuța settlement, where he offered medical services to "venereal patients". ${ }^{14}$ At the same time, ready to provide medical assistance at any time, he participated voluntarily in the fight against the plague. This is why he appears on the I3 May I829 list of physicians honoured by the Divan (Public Assembly) for "devotion in service" and on the 1830 list, when it is awarded by the Russian general Pavel Kiseleff, Plenipotentiary President of the Divans of Bucharest and Iași, with 2400 lei, in the contest given to fight the plague epidemic. ${ }^{15}$

The Protomedicus function was a true institution at the time, equivalent to the Ministry of Health today, with the distinction that at that time it was in the subordination of the Minister for Internal Affairs. The protomedicus was the one "who selected and recommended all the medical personnel in the country (physicians, feldshers, midwives)", watched "for everyone to fulfil his duty", maintained "correspondence with all the competent governors of the capital, counties, and quarantine points and at least once a year travelled throughout the Principality and informed the Vornic (the Minister for Internal Affairs) about everything concerning public health". ${ }^{16}$ In other words, the Protomedicus mobilised the healthcare system and made it work.

12 Arhivele Naționale Istorice Centrale, Bucharest (hereafter ANIC), Fond Catagrafii, file 82/1838, (195). See also Barbu, Gabriel (1967). Arta vindecării în Bucureștii de odinioară [The Art of Healing in the Old Bucharest], Bucharest: Editura Științifică, 260.

13 Cernovodeanu, Paul (1978), Date de interes medical din catagrafia orașului București de la 1838 [Data of medical interest from the Bucharest Cartography of 1838], in: Brătescu, G. ed., Din tradițiile medicinii și ale educației sanitare [From the traditions of medicine and health education], Oradea: Editura Medicală, 1978, 207. For the year of obtaining the university degree, see Buletin. Gazetă Oficială. Supliment Extraordinar la Buletinul Oficial [Bulletin. Official Gazette. Extraordinary Supplement to the Official Bulletin], nr. 45/1833, 245.

14 Bercus, Constantin I. (1976). Începuturile „ospiciului smintiților” de la Mărcuța [The beginnings of the "hospice of the mentally ill" from Mărcuța], in: Brătescu, Gh. ed., Spitale vechi și noi. Studii și note [Old and new hospitals. Studies and notes], Bucharest: Editura Medicală, 234; See also Buda, Octavian (2010). The face of madness in Romania: the origin of psychiatric photography in Eastern Europe, in History of Psychiatry, https://www. ncbi.nlm.nih.gov/pubmed/21879687 (accessed: 11 March 2020).

15 Samarian, Pompei Gh. (1938). Medicina și farmacia în trecutul românesc 1775-1834 [Medicine and pharmacy in the Romanian past 1775-1834], vol. II, Bucharest: Tipografia "Cultura", 182-183 (336).

16 Buletinul Oficial [The Official Bulletin], 89/1854, 353-354. 
At the same time, this institution conferred prestige, influence, and even high incomes to its leader.

\section{Doctor GUSSI ANd the LAW OF MODERnization OF THE MEDICAL SYSTEM IN WALLACHIA}

The founding act of the medical-sanitary system in Wallachia was the Organic Regulation. ${ }^{17}$ The document was prepared by the Romanian political class under the supervision of Pavel Kiseleff (1788-1872), the Governor of the Romanian Principalities during $1829-1834$, who had an essential role in the institutional and political transformation of the Romanian Principalities. ${ }^{18}$ Through the articles of public health it contained, the state announced a new initiative: healthcare for the entire population of the country. The new concern was closely linked to the economy and the wider process of modernization initiated by the state in the third decade of the nineteenth century, in the conditions of an appropriation of the Western political and cultural model by the country's elite. ${ }^{19}$

The main objective of the State was to turn medicine into a modern, accessible, and inexpensive public service. Although generous, the idea was not so easy to implement, and multiple questions started to emerge. How could the State provide medical care to all people? What medical services would be free? Were there human and financial means to ensure the functioning of the system? The answers to this kind of questions are found in the articles of public health of the Organic Regulation, which outline both the organisation and the financing of the medical system. These provisions started from the idea that medicine had to be distributed and controlled by the state through a simple form of financing: the government had to acquire money through taxes from the working population and distribute some of them for the health expenses of the entire population. In this way, the state

17 The Organic Regulation was a document with constitutional value, which was the basis of the modernization process of the Romanian Principalities (Wallachia and Moldavia) from 1831 to 1858 when it was replaced by the Paris Convention.

18 Popa, Bogdan (2016), Reformator sau cuceritor? Cariera lui Pavel Dimitrievici Kiselev în Rusia și în Principatele Române [Reformer or Conqueror? Pavel Dimitrievici Kiselev's Career in Russia and in the Romanian Principalities], în Achim, Venera, Achim, Viorel (eds), Modernizare socială și instituțională în principatele române 1831-1859 [Social and Institutional Modernization in the Romanian Principalities 1831-1859], Bucharest: Editura Academiei Române, 45-57.

19 Boia, Lucian (2001). Romania. Borderland of Europe, translated by James Brown. London: Reaktion Books, 79. See also, Keith Hitchins (1996). The Romanians, 1774-1866. Oxford: Clarendon University Press, 201-205. 
could organise a national health system that would rationalise the medical services and strictly control and pay the medical professionals. ${ }^{20}$ In the beginning, the medical system took the form of the quarantine service and medical departments. In order to watch over its proper functioning, three institutions were put in place: the Protomedicus, the Quarantine Committee and the Doctoral Commission. In general, four issues were considered a priority by the government: stopping epidemic waves (plague, then cholera), immunisation against smallpox, hospitalisation of venereal disease patients, and decreasing morbidity and mortality.

Once the medical policy was established, the next question was how to provide health care to the people of cities and villages when the reality of the moment revealed a chronic shortage of physicians and qualified medical aids (feldshers, midwives, vaccinators, etc.) in the medical system. How can you provide a reasonable number of professionals that you can point to either the poor urban or to the rural world? The answer to these kinds of questions was well known by the ruling authorities of the time: by setting up medical schools. The medical school was the solution to the lack of specialists. However, it was not easy to set up a school in Wallachia during those years. On the one hand, the financial resources were scarce, on the other, in the context of an amplifying national sentiment, the leaders feared the power education enabled; the possibility of a critical mass, capable of questioning the existing social order was frightening. Education reform has been greatly influenced by foreign powers (The Russian Empire and Ottoman Empire), which sometimes manifested as pressure factors in the Romanian society. ${ }^{21}$ However, on 10 January 1842, through the efforts of physician Nicolae Kretzulescu (son of a great boyar, educated in Paris), the School of Small Surgery at Colțea hospital, in Bucharest would be established. It was the second medical school set up in Wallachia. Since 1839, a Midwife School was also functioning in Bucharest. After two years of study, school graduates received a diploma that legitimised their ability to treat patients in accordance with the scientific norms and procedures of the time. More exactly, they were taught to vaccinate, to practice phlebotomy very precisely (how much blood to "take once" and from what place), to put leeches, to "pull out the teeth" or

20 Negulescu, Paul, Alexianu, George eds. (1944). Regulamentele Organice ale Valahiei și Moldovei [Organic Regulations of Wallachia and Moldavia], Bucharest: Întreprinderile "Eminescu" S.A., 182-185.

21 Regarding the state policy on school and culture, I refer to Drace-Francis, Alex (2006). The Making of Modern Romanian Culture. Literacy and the Development of National Identity, London: Taurus Academic Studies. 
just to "clean" them, to apply patches, suction cups and blisters. ${ }^{22}$ They also knew for sure what not to do: write recipes and perform "significant operations without the supervision of a doctor". ${ }^{23}$ With such knowledge, teachers hoped to reduce the number of fatal accidents, especially due to the way phlebotomies were practised and to gain people's trust in the therapeutic possibilities of medicine.

We will not discuss here the obstacles that the "School of Midwifery" and the "School of Small Surgery" would have to face when trying to widen the curriculum and the school grid, neither their temporary closure, nor about their efforts to reopen. As we said, everything is due to the geopolitical context of the period, financial resources, and rulers' prudence. It is important to emphasise that the institutionalisation of the medical specialisation (of midwives and feldshers) and its confirmation through a diploma began with these two schools with a sporadic existence. Once graduating, the new specialists could dream of a career in the state medical service (or in the private sector), with a monthly salary, a guaranteed retirement at the end of the career, and a minimum abundance for them and their family. Finally, as the number of midwives and feldshers with a diploma increased, so did the awareness of belonging to a common profession.

In this context, the comparison with the situation in Transylvania is tempting, because Moldavia (the other Romanian Principality, which is now, together with Transylvania, a province of Romania) registers a situation similar to that in Wallachia. ${ }^{24}$ Integrated into the Habsburg Monarchy, Transylvania looked quite different compared to the two Romanian principalities. Regarding healthcare, the province had a better situation: it had hospitals with local medical clinics and professionals (midwives, surgeons, pharmacists, and physicians), trained in schools and faculties in the Habsburg Empire (Vienna, Graz, Buda, etc.), in university centres from Prussia and the Netherlands, and even in Transylvania (in Cluj/Kolozsvár and Sibiu/ Nagyszeben). For example, the Surgical Lyceum in Cluj trained specialists in the field of birth care (midwives) and surgery since i790. After a series of metamorphoses, like the one from I8I7, when the Royal Academic Lyceum became the Medical-Surgical Institute, on the foundation of the

Buletin. Gazetă Oficială, 7/1842, 26.

Ibid.

24 Pruteanu, Paul (1957). Contribuție la istoricul spitalelor din Moldova. Spitalele din Moldova dependente de Epitropia generală a Casei Sf. Spiridon, de la primele începuturi până la unirea serviciilor sanitare ale Moldovei și Munteniei [Contribution to the history of Moldavian hospitals], Bucharest: Editura Medicală, 200-210. 
medical institution was established the Royal University of Cluj (in 1872), with four faculties, including the Faculty of Medicine. ${ }^{25}$

The story of the physician profession is longer and more complicated. The Romanian Medical Faculty was established in 1869, in Bucharest, followed in 1879 by the one in Iași, in Moldavia. Until the society could benefit from physicians trained in a Romanian school, it had to resort to foreign physicians. In order to attract these physicians to Wallachia, the governance offered them attractive salaries and privileges. The beginning of this process can be seen in a list of physicians who were investigated by the Physicians Commission and had diplomas, made public on 18 September I833. According to it, 42 physicians officially requested and received the certificate of free practice in Wallachia, of these 27 were "doctors of medicine and surgery" and only 15 were "magisters of surgery". ${ }^{26}$ Eighteen years later, the protomedicus Gussi undertook a new numerical evaluation of the physicians in the Wallachian health service. The list of the acting physicians in the Principality is published on 6 June i85r. An inventory we have made reveals the following figures: 53 "doctors of medicine", I2 "magisters of surgery", I3 "patrons of surgery", one "proto-veterinarian" and one "vice-veterinarian". ${ }^{27}$ In total: 78 physicians and two veterinarians took care of a population of almost 2,500,000 inhabitants and their animals. Although these numbers should be regarded more as approximations than precise data, we estimate that in $185 \mathrm{I}$, a physician from Wallachia was responsible, on average for 32,000 inhabitants. Generally, data suggest that the physicians were overwhelmed: their services could not cover the demand for healthcare on the market. The list of physicians also indicates something else: besides a few notable exceptions (for example, Nicolae Kretzulescu, Gheorghe Polizu, and Ștefan Capșa), the physicians were foreigners. In comparison with the list of $\mathrm{I}_{33}$, it is clear that the situation was not stalling, as the number of physicians almost doubled and some local specialists also appeared. However, these aspects are more important by significance than by the practical results obtained.

It should be noted that these numbers are based on official figures only. It is fair, in this context, to mention the physicians not registered by the Doctoral Commission, at the same time not referring to the impostors who

25 Karady, Victor, Nastasă, Lucian (2004). The University of Kolozsvár/Cluj and the Students of the Medical Faculty (1872-1918), Budapest/Cluj-Napoca: Ethnocultural Diversity Resource Center, 49-53. See also Sechel, Teodora, Daniela (2008), 106-109.

26 Buletin. Gazetă Oficială. Supliment Extraordinar la Buletinul Oficial, 45/1833, 249

27 Buletin Oficial al Prințipatului Țării Românești, 58/1851, 229. 
falsely claimed to be physicians. Various sources, such as reign laws, lists made by district commissions that remained in archives, diplomatic texts, writings of foreign travellers, and newspapers mention them. For various reasons (either they did not intend to permanently settle in Wallachia and did not see the purpose of the certification, already having a free practice permit, obtained in the country where they graduated from the university $y^{28}$ or were "dissidents" - specialists not recognized by the university science), they did not attend the Doctoral Commission to verify their diploma and obtain the right of free practice. This does not mean that they were not here and did not profess. The problem is that we do not know exactly how long they stayed in Wallachia and where they worked.

We should also mention that during this period, the typical physician from Wallachia or Moldova lived almost exclusively in cities, his services mainly targeting the urban population. These physicians worked as freelancers, even if entrusted with functions in the service of the state and their interest was first to have a reliable clientele and then to provide medical services to patients without financial possibilities or to be present where the administration sent them. The rural area, despite the frequent invocations in reports, was not particularly of interest for them. The reason is that the paying clientele is rare and scattered, being reached with great effort, at the end of long and tiring journeys, by carriage or horseback. In addition, the peasants did not sympathise with the physicians who were too different, came from a different socio-economic background, expressed themselves in a precious, hard to understand language, and practised an expensive service, whose therapeutic efficacy they doubted.

By 1850, Nicolae Gussi concluded that Wallachia needed a major reform in the medical sector and fully dedicated himself to this cause. For two years, he was working on "The project for the extension of the sanitary facilities and improvement of the medical service", but not alone, the reform also being almost unanimously desired by people from the Doctoral Commission and the Ministry of Internal Affairs. On 27 March 1853 , prince Barbu Știrbei (I849-1856) signed the project, giving it the status of law. The essence of this law was that it transformed the temporary municipality hospitals into permanent hospitals. By doing this, the power sought to create a network of

28 For the doctors who already had the right of free practice (obtained in Western countries) the date when they settled in Wallachia is mentioned in article 2 of the Law of the extension of health settlements and the improvement of the medical service (1853). See Buletin Oficial, 16/1853, 61. I thank Professor Nicolae Marcu for the guidance on this subject. 
hospitals in the country, to control both "syphilitic disease", which was said to have spread over all classes of people, even throughout villages, and the common affections from which the inhabitants of counties, both villagers and townspeople suffered. ${ }^{29}$ Moreover, in the second article, the law stipulated that physicians with the degree of "doctor of medicine", and the right of free practice obtained in the state where they graduated from faculty should be placed in these hospitals. ${ }^{30}$

Other articles of the law concerned the proper functioning of the medical system. In order to avoid conflicts within the medical staff or institutional misunderstandings, caused by contradictory indications or decisions, overlapping tasks or conflicts of interest, salaries or budgetary restrictions, or various central or local administration deficiencies, the responsibilities have been carefully specified for each specialization (physician, surgeon or feldsher), the salaries were fixed for all the medical staff, and rules of coordination and subordination between different entities were established.

Therefore, for a salary of 800 lei per month, a physician working in the county cities had several services in his job description: holding free examinations at the hospital or the place meant for a future hospital setting, each and every day, between the hours of 9 and II. The physician also had to visit the home of poor, ill people, extraordinary and urgent events, and, in the case of epidemics or epizootics, personally go to the counties to investigate and spot the cause of those incidents and take preventive measures. He had to monitor the drugstores closely, coordinate the vaccinations of children in the cities and villages of the county, undertake a yearly inspection through the villages of the county, in order to verify the implementation of different health measures. Further, he had to be present at the examination of police recruits, execution of autopsies, and at everything that relates to the medical profession or legal medicine. Finally, at the end of each month, he had to draw up a report to the Committee on the state of health and the taken measures. ${ }^{31}$ All these services were meant, in the legislator's view, to provide

29 Proiect de întinderea așezămintelor sanitare și îmbunătățirea serviciului medical [Project for the extension of health settlements and the improvement of the medical service] (1853). Buletinul Oficial, 16/1853, 61 .

30 Ibid., p. 61. A brief presentation of the law by Felix, Iacob (1901). Istoria igienei în România în secolul al XIX-lea și starea ei la începutul secolului al XX-lea [The history of hygiene from Romania in the 19th century and its state at the beginning of the 20th century], vol. I, Bucharest: Institutul de Arte Grafice Carol Göbl, 43-44.

31 Buletin Oficial, 16/1853, p. 61. 
good care for the diseased, in the towns and villages of counties and more importantly, to supervise the population medically.

We have to admit that not a single person has been able to cope with so many tasks. Therefore, the law provided in the third article that doctor delegated part of these services, under certain conditions, to two members of his team: the surgeon and the feldsher. The patients outside the city were placed in the surgeon's care; he gave consultations on request, prescribed free treatments, and vaccinated children. In addition, if the hospital physician was not in town for any reason, the surgeon would take over all the services and responsibilities of the physician except for the salary. The salary of a "physician-surgeon" was set at 400 lei per month. The feldsher was responsible for "helping physicians with bloodsucking, applying suckers and the like", vaccinating children from towns and villages, searching for the poor sick people, and examining cattle meant to be slaughtered. In exchange for these services, the state rewarded him with two hundred lei per month. ${ }^{32}$ The law also finds a solution for increasing their number: a small surgery course would be reinitiated in Bucharest, in which "some science of the veterinary arts should also enter". ${ }^{33}$

A few paragraphs of the third article requested an increase in vaccinations and the training of those entrusted with their good management. The chosen solution comprised the division of the county into two regions, one for the surgeon and the other for the feldsher, and the logistics for transporting the two servicemen in the corresponding territory. ${ }^{34}$

In the fourth article, the law regulated the situation of the quarantine physicians: they remained only in the service of their settlements and could only leave their post in some extraordinary, urgent circumstances. Their status in the hierarchy of the medical system was similar to that of the county or hospital physician. Like them, in order to be selected, appointed, or confirmed to the position, it was obligatory to hold the title of "doctor of medicine", which is equivalent to today's general practitioner. ${ }^{35}$

In practice, the way physicians were hired in important positions of the medical administration is a source of dissatisfaction and controversy on both sides. The voice of these dissatisfactions was the Administration of Civil Hospitals. Since I842, the Administration suggested the establishment

\footnotetext{
Ibid., p. 61.

Ibid., p. 62.

Ibid., p. 61.

35 Ibid., p. 61.
} 
of a contest for the appointment of doctors in public medical positions. They also drafted an examination project, which they presented to the Doctoral Commission and the Quarantine Committee for approval. ${ }^{36}$ However, the commissioners were not convinced by the usefulness of the project: they submitted it to the Commission's archive, and the problem was postponed. In 1859 , there was still no regulation or provision specifying the selection criteria for a position in the medical system. An explanation for this disengagement is offered by the protomedicus Gussi himself, shedding light on why the law of 1853 circumvented this aspect. The story began on 5 March 1859 , when Gussi received a petition from the Administration of Civil Hospitals, where he was asked to organise a contest for the vacant position of "doctor of medicine" at the hospital in Ploiești. ${ }^{37}$ Gussi's answer was categorical, he did not see the purpose of the examination because "such a contest, which is neither foreseen in any legislation nor was an example, to this day in our country, if it is to be given by any doctor, over the lawful examination that is held by the Medical Council when he is entrusted with his profession, could discourage even those who would hopefully receive the vacancy from Ploiești, because of 23 physicians without jobs, no one intends to go out to the counties, everyone aspiring to work here", in Bucharest. Finally, Gussi recommended: "from now on, none of the physicians who come to the country should work in any commission of the capital, until first serving three or four years in the counties". ${ }^{38}$ The issue was to be resolved a few years later by Carol Davila (1828-1884), probably of French origin and naturalised Romanian citizen, the new director of the medical administration (in I860, Davila initiated the practice of competition for public positions in the medical system). ${ }^{39}$

The fifth article of the law had a specific purpose. It transformed the Doctoral Commission into the "Medical Council of the Principality" and gave it one more duty: "researching the medical capacity of the physicians who want to practice this profession". ${ }^{40}$ With this, the practise of examining the medical knowledge of the physicians in Wallachia was introduced. We

36 Proiect pentru examenul doftorilor, chirurgilor și a moașelor [Project for the examination of doctors, surgeons and midwives], in Gălășescu, Al. G. (1906). Eforia Spitalelor Civile din București [Administration of Civil Hospitals in Bucharest], Bucharest: Minerva. Institutul de Arte Grafice, 406.

37 Ibid., p. 461.

38 Ibid., p. 461-462.

39 Cotoi, C. (2016), 167-168; Bărbulescu, C. (2015), România medicilor. Medici, țărani și igienă rurală în România de la 1860 la 1910 [The physicians' Romania: Physicians, peasants, and rural hygiene in Romania from 1860 to 1910], Bucharest: Humanitas, 309.

Buletinul Oficial, 16/1853, 61. 
recall that until then, the Commission had only verified the doctor's specialisation diploma, on whose behalf the certificate of free practice was issued. Theoretically, the rules of the game changed since then. The physician acquired the right to free practice only after passing the medical knowledge test, but in practice, things did not go according to the article of the law. In fact, throughout Gussi's protomedicus mandate, the right of free practice was granted only by the examination of the specialisation diploma.

Other paragraphs of the fifth article settled the responsibilities of the city district physicians and set out the selection criteria and obligations of this position. In order to be a district physician, you had to hold the title of doctor "not only of medicine but also of surgery". Moreover, the doctor was forced to live in the "partition of the capital where he was sent" and work in a team with the feldsher, especially for the vaccination of all children in the district. For his services, the doctor received eight hundred lei per month and the feldsher two hundred lei per month. The protomedicus was leading the whole system, and the law increased his salary by an additional five hundred lei per month, from rooo to 1500 lei. Last but not least, the law guaranteed for all medical staff the same rights, distinction, and pension as for the other "state servants" ${ }^{41}$ In other words, the physician was transformed into a civil servant, controlled and paid by the system.

With these regulations, the law brought more order to the health administration and, reading between the lines, it set two objectives: to reduce infant mortality through vaccination and hygiene and reduce morbidity by reserving minimal medical assistance to the needy population of cities and villages, who could not afford it otherwise.

It is instructive to find out and remember how things really unfolded. Regarding the hospitals, at first glance, things seemed to be going as planned. According to official data, in only two months, hospitals were operating in all the counties of Wallachia, mainly for venereal diseases. They were arranged as modest public establishments (with 8 to 20 beds), with two equally important utilities: on the one hand, they served as a free (or paid) care centre for hospitalized patients hoping for a cure and, on the other hand, as an information outpost for the medical supervision of the population. On 6 June 1853 , the first article of the law was supplemented by the specification that county hospitals having permanent status shall be called "county

41 Ibid., 61-62. 
hospitals" ${ }^{42}$ On this occasion, two inspectors for the venereal hospitals were also employed. Their role in the mechanism of the medical system was to inspect the condition of the hospitals, the activity of physicians and other medical staff, and then to write a report to the Quarantine Committee and the Medical Council. Based on these reports, the protomedicus made a summary that was sent to the Minister for Internal Affairs for a wider analysis. ${ }^{43}$

The first reports prepared by the inspectors express a complete disappointment. There is a long list of problems in hospitals. Everything from infrastructure to logistics and specialists was deficient. Furthermore, venereal disease patients refused to be hospitalised.

Looking closer, the refusal of the venereal disease patients to receive medical care in the county hospitals seemed to be an old problem. Since I843, together with the employment of county physicians, the medicalisation of these patients had been attempted. With all the discretion of the physicians, most patients, for various reasons, did not want to hear about hospitalisation and refused to declare that they were suffering. Historian Bogdan Mateescu explains the reservation of these patients from the rural world through three aspects: "leaving the work on the land, relocation, but especially the interaction with the police and the physician". ${ }^{44}$ The reasoning is accurate because, for economic reasons, until 1853 , these hospitals were open only during the hot season, and the operating time coincided with the busiest period of the peasant (the work on the fields). We should also add a nuance; looking at the documents from the archive of the Administration of Civil Hospitals, we observe that the reluctance of the venereal disease patients to hospitalisation is only related to the seasonal hospitals because the hospitals that belonged to the Administration record another situation. For example, in 1843 , I253 patients were hospitalised and cared for at the Brâncovenesc hospital in Bucharest, of which 53I having venereal illnesses. At the end of the year "the

\footnotetext{
Ibid., 153.

Ibid., 154.

Mateescu, Bogdan (2016). Boală venerică, prostituție și construirea sistemului sanitar în Țara Românească (anii 1830-1850): provincia [Venereal disease, prostitution and the construction of the health system in Wallachia (1830-1850): the province], in VintilăGhițulescu, Constanța ed., Sexualitate și discurs politico-religios în societatea românească premodernă, Iași: Editura Universității „Alexandru Ioan Cuza”, 2016, 157. On the same subject, but a different location, Roman, Nicoleta (2016). Prostituția, boala venerică și construcția sistemului sanitar în București și județul Ilfov (1831-1859) [Prostitution, venereal disease and the construction of the health system in Bucharest and Ilfov county (18311859)], in Vintilă-Ghițulescu, Constanța ed. (2016), 227-298.
} 
list of hospitalisation" shows 467 cured, 59 relieved and five dead patients. ${ }^{45}$ In the following years, the number of venereal patients increased dramatically: 682 in 1844 and 795 in $1845 .{ }^{46}$

The situation did not change, even after the ${ }^{8} 853$ law and the patients' fear of hospitals and hospitalization was found throughout the nineteenth century. The physician Jacob Felix, vice inspector of the medical system and professor of hygiene at the Faculty of Medicine of Bucharest, trying to explain this fear, put the reservation of patients on account of the origin of the county hospitals: "the people did not forget the origin of these settlements and for a long time the entrance to them was considered shameful". ${ }^{47}$ This observation is accurate, considering that many county hospitals were established before 1853 and functioned as seasonal hospitals, exclusively for venereal diseases. The law of 1853 decided to establish permanent and multifunctional hospitals in all the county capital cities. Thus, the already existing hospitals were supplemented by new ones. For the population, neither the name change nor the multifunctional profile was significant. In their minds, the county hospital was linked to the image of a shameful illness, and those who entered it acknowledged that they were not "good Christians". Not coincidentally, starting from 1858 , priests were employed in hospitals to provide advice to patients. Another explanation relates to people's distrust of modern medicine and physicians, and their opposition to change. In support of this statement, we quote a record from 1872 , from J. Marini, a physician of the "Blue District" of Bucharest. While asking a citizen why his child was not looking for a physician, he received the following answer: "I took care of him, sir; I took the child to church and witches, and if with prayers and spells he could not heal, what could the physician do more?" ${ }^{\prime 8}$

Going back to the consequences of the reform, after three years and other reports, we spot old and new problems alike. Looking into protomedicus Gussi's report from March 1856 , to the Ministry for Internal Affairs, we find that most of the county hospitals were arranged in rented houses and had problems with space, beds, heating, furniture, tools, and residents (medical

45 Gomoiu, Victor, Plătăreanu, V. (1937). Centenarul Spitalului Brâncovenesc (1837-1937) [The Centenary of the Brâncovenesc Hospital (1837-1937)], Bucharest: Monitorul Oficial și Imprimeriile Statului, 68-69.

46 Ibid., p. 71- 74.

47 Felix, I. (1901), 34.

48 Gazeta medico-chirurgicală a spitalelor [Medical-Surgical Gazette of Hospitals], 16/1872, 249. 
staff and patients) ${ }^{49}$ Not much progress was made during the three years since they were set up. However, Gussi points out that he repeatedly tried to convince the hospital commissions to supplement their medical staff and to care for the settlements more heartily. By far, the hospitals that did not live up to their duties so far and were in poor condition were located in the Mehedinți, Teleorman, Dâmbovița, Argeș, Buzău, and Brăila counties. In the report, Gussi called for the minister's support, to intervene among hospital supervisors and commissions to take appropriate measures and to bring the hospitals in the best possible condition..$^{50}$ This is exactly what the Minister of Internal Affairs did. On I May I856, an announcement sent to all the county officials stated that "by collaboration with the commissions they should bring the hospitals in the most pleasant condition possible". ${ }^{51}$

These permanent requests for help from the protomedicus are an indirect consequence of the centralization of the healthcare system. Although he led the health administration and was the head of the Superior Medical Council and the Public Health Committee, he did not have sufficient autonomy and authority. Almost any intervention in the system or for any project modification required the permission and authorization from the Ministry for Internal Affairs.

The medical staff did not fare too well either. Between March and June I853, the Medical Council investigated the posts in the Wallachia sanitary administration. The names and numbers of physicians and other medical administrative posts were promulgated by the governor of Wallachia on 9 June $1853 .{ }^{52}$ The organisational chart clearly shows that under the appearance of an organisation, the system had significant shortcomings. The law required the establishment of permanent hospitals in all the county municipalities of Wallachia and also of a team of six professionals for the supervision of public health, consisting of two "doctors of medicine" (one occupying the position of "physician of the county", the other of "physician of the city" or "physicians of the hospital"), a surgeon (the hospital or county surgeon), and three feldshers (of the hospital, of the city, and of the county). Some midwives were certainly required, but the law did not remember them. Together, they were going to offer a range of medical services and hygiene advice to patients, watch over the endemic and epidemic phenomena, keep the

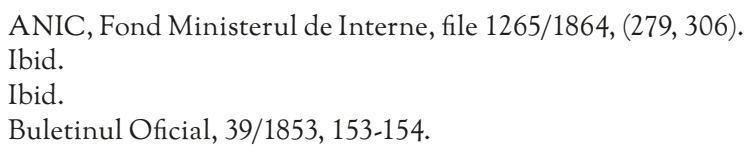


authorities informed on the health of the population, the sanitary situation of the region, the medicalisation of venereal disease patients, and the immunisation of children against smallpox.

The real situation revealed that $\mathrm{I} 6$ out of $\mathrm{I} 7$ counties in Wallachia had personnel problems. Dolj County did the best, having a complete team (a physician, two surgeons, and three feldshers). Four other counties - Brăila, Ilfov, Muscel, and Râmnicu Sărat - had the two physicians requested by law, but they did not have surgeons or feldshers. The rest of the counties were coping with a physician and three feldshers. ${ }^{53}$ In 1854 , a new list of the county medical staff was published. An improvement was expected in meeting the law requirements. However, except for the counties of Brăila, Buzău (both had a physician, a surgeon, and two feldshers), and Prahova (a physician, a surgeon, and a feldsher), solving people's health problems depended on a doctor and three feldshers. ${ }^{54}$ Four years later, in 1858 , the data remained unchanged regarding the doctors and the rest of the medical staff, but a new official, a priest of the county hospital, appeared on the list. ${ }^{55}$

It can be said that setting up a medical team made up of three doctors (two physicians and a surgeon) and three feldshers in the county residences, as the law said, was an impossible task to accomplish during this period. Various explanations were given, and most of them proposed the excuse that no financial resources had been found to complete the staffing grid required by law. That was probably the case, although the ${ }_{1} 853$ law was accompanied by a budget for incomes and expenses, clearly specifying from where the sums should be taken (from the treasury, from the municipal houses of cities and towns, from the funds of Filantropia, Ploiești, and Buzău hospitals, from the "Ionașcu from Slatina fund"), in what percentage, and how much should be given to each employee. ${ }^{56}$ Other justifications are possible: either the jobs were not attractive to the physicians, or the job demand massively exceeded the supply. So far, the conclusion is that the formula of one physician and three feldshers for each county was accepted. The success of the medical reform depended on them.

These reforms required more time because the signals that arrived at the Medical Council in the first years after the implementation of the law were

Ibid.

54 Almanah al Statului pe anul 1855 [Almanac of the State for 1855], Bucharest: Tipărit la Zaharia Carcalechi, 1855, 78-82.

55 Almanah al Statului pe anul 1858, Bucharest: Imprimeria Mitropolitului Niphon, 1858, 61-65.

56 Buletinul Oficial, 16/1853, 62. 
not very encouraging. Physicians were accused that, although they were well paid, they were not involved enough, limited themselves only to what is passed in the regulation, had no initiative, and did not know what personal responsibility entails. In other reports, it is emphasised that physicians abandoned their jobs after a few months from the appointment, but no explanation is provided. The reason is found in the reports of county physicians to the "Honest Committee". They emphasised that they had not been paid on time, and often several months to a year passed without payment. ${ }^{57} \mathrm{We}$, therefore, can explain the reluctance of many physicians to work solely in the state medical service.

In Bucharest, the capital of the country, we see a situation close to the letter of the law. Here, the recruitment of physicians in the city medical service did not raise any particular problems. A list publicized in 1853 shows that each district of the capital had a team of three specialists (a physician, a feldsher, and a midwife). ${ }^{58}$ In addition, at extraordinary events, they were assisted by the surgeon, the proto-veterinarian, or the veterinarian. ${ }^{59}$ This fact is all the more worth remembering, as a district physician had to have solid university studies, specifically to be a doctor of "medicine and surgery". Also, according to the rules governing their activity, their services were not limited to the population of the capital. They were commissioners of public health, and they had to manage the medical service in the country. Often, the multitude of responsibilities was reflected in the quality of decisions as problems of an urgent nature, and the obligation to take immediate decisions led to the creation of evasive and fragile regulations or measures, which, in time, generated dysfunctions and inconsistencies.

After all, beyond the shortcomings of all kinds, the institution of the "county hospital" was conceived as a structure of medical authority, closer to the small communities in villages and trade outposts. With the help of physicians, the hospital had to medicalise the rural world quickly and radically. Unfortunately, its efficiency largely depended on the state's human and financial resources. Some were insufficient, and others were completely missing. The impediment is that one cannot build something to the end only with good intentions and competent strategies, without people, financial resources, and tools for action and constraints.

\footnotetext{
ANIC, Fond Comitetul carantinelor, file 2/1854, (183 and 591).

Buletinul Oficial, 16/1853, 62.

Ibid., p. 154.
} 


\section{Conclusion}

Starting with the first decades of the igth century, through the political will and enthusiasm of a generation of Romanian intellectuals (mostly among the great boyars), a process of modernization was launched in Wallachia and Moldavia that targeted all areas and aspects of society. The medical dimension was not lacking in this process. Between 1830 and 1840 , a medical system was set up, which initially took the form of the Quarantine Service and Medical Departments. Then, year after year, through a series of normative acts and bills, the system would improve. At the end of 1859 , in each county of Wallachia, there was a multifunctional hospital, financially supported by the state, where a physician, a surgeon, three feldshers, and a few midwives provided some free medical services (such as vaccination against smallpox, treatment of syphilis or contagious diseases, etc.).

In the beginning, the organisation model of the system was the German one, especially at the level of institutions and medical-sanitary rules (the Quarantine System was inspired by the quarantine structure of the Habsburg Monarchy), but also taking into account the training of professionals (most physicians who worked in the medical system were trained in the universities of the German cultural space). From 1853, with the arrival of Carol Davila, the system received a strong French infusion, and after the Health Law of 1874, the influence of the French health model would increase and become decisive.

As for the state's medical policy, it followed the hygienic current of the time, as in all of Europe and even in the Ottoman Empire. The idea was that through social reforms and hygiene, the population would increase, and the quality of life would improve.

\section{AcKnowledgments}

My special thanks for the anonymous reviewers whose valuable comments have greatly improved this study. 


\section{BiBLIOGRAPHY}

\section{MANuscript SOURCES}

1. Arhivele Naționale Istorice Centrale, Bucharest (hereafter ANIC)

2. ANIC, Fond Catagrafii, dos. $82 / 1838$

3. ANIC, Fond Comitetul carantinelor, ds.2/1854.

4. ANIC, Fond Ministerul de Interne, dosar 1265/1864.

\section{Newspapers and Periodicals}

1. Almanah al Statului pe anul 1855 (1855), București, Tipărit la Zaharia Carcalechi

2. Almanah al Statului pe anul 1858 (1858), București, Imprimeria Mitropolitului Niphon.

3. Buletin. Gazetă Oficială. Supliment Extraordinar la Buletinul Oficial, 45/1833

4. Monitorul Oficial al Țării Românești, nr. 109/ 11 septembrie 1859.

5. Gazeta medico-chirurgicală a spitalelor, nr. 16, 1 octombrie 1872.

\section{SECONDARY SOURCES}

1. Barbu, Gabriel (1967). Arta vindecării în Bucureștii de odinioară [The art of healing in the old Bucharest], Bucharest: Editura Științifică.

2. Bercus, Constantin I. (1976). Începuturile „ospiciului smintiților” de la Mărcuța [The beginnings of the "hospice of the mentally ill" from Mărcuța], in: Brătescu, Gh. ed., Spitale vechi și noi. Studii și note [Old and new hospitals. Studies and notes], Bucharest: Editura Medicală, 1976.

3. Bărbulescu, Constantin (2015). România medicilor. Medici, țărani și igienă rurală în România de la 1860 la 1910 [The physicians' Romania: Physicians, peasants, and rural hygiene in Romania from 1860 to 1910], Bucharest: Humanitas.

4. Buda, Octavian (2010), The face of madness in Romania: the origin of psychiatric photography in Eastern Europe", in History of Psychiatry, 21 (3), 278-293.

5. Cernovodeanu, Paul (1978), Date de interes medical din catagrafia orașului București de la 1838 [Data of medical interest in the Bucharest Cartography from 1838], in: Brătescu, Gh. ed., Din tradițiile medicinii și ale educației sanitare [From the traditions of medicine and health education], Oradea: Editura Medicală, 1978.

6. Cotoi, Călin (2016). Cholera, Health for All, Nation-Building, and Racial Degeneration in Nineteenth-Century Romania, East Central Europe, 43 (1-2), 162-184.

7. Drace-Francis, Alex (2006). The Making of Modern Romanian Culture. Literacy and the Development of National Identity, London: Taurus Academic Studies. 
8. Gălășescu, Al. G. (1906). Eforia Spitalelor Civile din București [Administration of Civil Hospitals in Bucharest], Bucharest: Minerva. Institutul de Arte Grafice.

9. Gomoiu, Victor, Gomoiu, Gh., Gomoiu, Maria V. (1938). Repertor de medici, farmaciști, veterinari din ținuturile românești [Directory of doctors, pharmacists, veterinarians from the Romanian lands], vol. I, Braila: Tipografia „Presa”.

10. Gomoiu, Victor, Plătăreanu, V. (1937). Centenarul Spitalului Brâncovenesc (1837-1937) [The centenary of the Brâncovenesc Hospital (1837-1937)], Bucharest: Monitorul Oficial și Imprimeriile Statului.

11. Felix, Iacob (1901). Istoria igienei în România în secolul al XIX-lea și starea ei la începutul secolului al XX-lea [The History of Hygiene from Romania in the 19th Century and its State at the Beginning of the 20th Century], vol. I, Bucharest: Institutul de Arte Grafice Carol Göbl.

12. Frevert, Ute (1985). Professional Medicine and the Working Classes in Imperial Germany, Journal of Contemporary History, 20 (4), pp. 637-658.

13. Karady, Victor, Nastasă, Lucian (2004). The University of Kolozsvár/Cluj and the Students of the Medical Faculty (1872-1918), Budapest/Cluj-Napoca: Ethnocultural Diversity Resource Center.

14. Leski, Erna (1976). The Vienna Medical School of the 19th Century, Baltimore/ London: Johns Hopkins University Press.

15. Livadă-Cadeschi, Ligia (2013). Discursul medico-social al igieniștilor români. Abordarea specificităților locale din perspective experiențelor occidentale europene, secolele XIX-XX [The medical-social discourse of the Romanian hygienists. Approaching local specificities from the perspectives of Western European experiences, 19th-20th centuries], Bucharest: Editura Muzeului Național al Literaturii Române.

16. Mateescu, Bogdan (2016). Boală venerică, prostituție și construirea sistemului sanitar în Țara Românească (anii 1830-1850): provincia [Venereal disease, prostitution and the construction of the health system in Wallachia (1830-1850): The Province], in Vintilă-Ghițulescu, Constanța ed., Sexualitate și discurs politico-religios în societatea românească premodernă, Iași: Editura Universității „Alexandru Ioan Cuza”, 2016.

17. McClelland, Charles E. (1991). The German Experience of Professionalization: Modern Learned Professions and Their Organizations from the Early Nineteenth Century to the Hitler Era, New York: Cambridge University Press

18. Nazarska, Georgeta (2010). The Vienna School of Medicine and Bulgarian Medicine and Health Care (the 1840s-1910s): Transfer of Knowledge, in Sechel, Teodora Daniela ed., Medicine Within and Between the Habsburg and Ottoman Empires 18th -19th centuries, Bochum: Dr. Dieter Winkler Verlag, 2010. 
19. Pruteanu, Paul (1957). Contribuție la istoricul spitalelor din Moldova. Spitalele din Moldova dependente de Epitropia generală a Casei Sf. Spiridon, de la primele începuturi până la unirea serviciilor sanitare ale Moldovei și Munteniei [Contribution to the history of Moldovan hospitals], Bucharest: Editura Medicală.

20. Samarian, Pompei Gh. (1938). Medicina și farmacia în trecutul românesc 1775-1834 [Medicine and pharmacy in the Romanian past 1775-1834], vol. II, Bucharest: Tipografia „Cultura”.

21. Sechel, Teodora, Daniela (2008). The Emergence of the Medical Profession in Transylvania (1770-1848), in Cultural Dimensions of Elite Formation in Transylvania (1770-1950), edited by Victor Karadi and Borbala Zsuzsanna Tőrők, Cluj-Napoca, Ethnocultural Diversity in Romania Series, p. 95-114.

22. Vintilă-Ghițulescu, Constanța (2015). Patimă și desfătare Despre lucrurile mărunte ale vieții cotidiene în societatea românească (1750-1860) [Passion and delight. About the small things of daily life in Romanian society (1750-1860)], Bucharest: Humanitas.

\section{SAŽETAK}

Glavni je cilj ovog istraživanja dati pregled razvoja medicinskog sustava u pokrajini Vlaškoj između I840. i I860. i vrlo važne uloge liječnika Nicolaea Gussija (I802. - I869.), protomedikusa Vlaške između I840. i 1859., u preobrazbi medicine u modernu javnu uslugu, dostupnu cjelokupnom stanovništvu. Osobito ćemo se osvrnuti na projekt medicinske reforme iz I853., koji je Gussi proveo u vrijeme dok je bio na čelu medicinsko-sanitarne uprave. Usredotočit ćemo se na detalje projekta koji je osmišljen kako bi stvorio mrežu regionalnih bolnica koja bi poboljšala zdravlje stanovništva te bi, u srednjoročnom i dugoročnom razdoblju, smanjila smrtnost $i$ produžila životni vijek. Sljedeća dimenzija istraživanja usmjerena je na rad liječnika u regionalnim bolnicama te opisuje medicinske usluge koje su pružali pacijentima, posebice siromašnoj populaciji.

Ključne riječi: medicinske ustanove, medicinske politike, liječnici, bolest, modernizacija 